\title{
DETERMINAN VARIABEL MONETER TERHADAP INDEKS HARGA SAHAM GABUNGAN (IHSG) DI INDONESIA TAHUN 2005-2018
}

\author{
Hamzah $^{1}$, Devi Putri ${ }^{1}$, Andre Riswanto ${ }^{1}$, Gebila ${ }^{1}$ \\ Universitas Bangka Belitung \\ * Email: hamzahsuju@gmail.com
}

\begin{abstract}
ABSTRAK: Indeks Harga Saham Gabungan (IHSG) merupakan salah satu indikator yang menunjukkan keadaan ekonomi pada suatu negara. Semakin baik Indeks Harga Saham Gabungan, maka semakin baik pula perekonomian pada suatu negara tersebut. Di Indonesia Indeks Harga Saham Gabungan mengalami nilai yang fluktuatif dalam rentan waktu tiga belas tahun terakhir. Penelitian ini bertujuan untuk menganalisis Determianan Variabel Moneter terhadap Indeks Harga Saham di Indonesia pada periode 2005-2018. Variabel Moneter yang digunakan adalah Inflasi dan BI Rate serta terdapat juga variabel pendukung seperti American Dollar dan Politik. Kebijakan Moneter dari pemerintah Indonesia memiliki dampak penting terhadap bagaimana negara-negara ini mengelola pasar modalnya. Metodologi yang digunakan pada penelitian ini adalah menggunakan analisis regresi dengan perumusan pengaruh antar variabel. Hasil menunjukkan bahwa Variabel Moneter (Inflasi dan BI Rate), American Dollar, dan Politik memilki pengaruh yang negatif terhadap Indeks Harga Saham Gabungan, namun hanya variabel Inflasi yang memiliki pengaruh yang signifikan.
\end{abstract}

Kata kunci: IHSG, Variabel Moneter, Politik.

\section{Pendahuluan}

Indeks Harga Saham Gabungan (IHSG) merupakan salah satu indikator yang digunakan investor untuk melihat kondisi perekonomian suatu negara. Pergerakan nilai Indeks Harga Saham Gabungan akan menunjukan situasi pasar yang sedang terjadi. Pasar yang sedang aktif ditunjukan dengan Indeks Harga Saham Gabungan yang mengalami kenaikan sedangkan pasar yang lesu ditunjukkan dengan penurunan nilai Indeks Harga Saham Gabungan. Melihat hal ini maka dilakukan penelitian mengenai faktor yang mempengaruhi Indeks Harga Saham Gabungan yaitu Inflasi, BI Rate, American Dollar, dan Politik. Menurut Widoatmojo (1996) Indeks Harga Saham Gabungan merupakan ringkasan dari dampak simultan dan kompleks atas berbagai macam faktor yang berpengaruh, terutama fenomenafenomena ekonomi. Bahkan dewasa ini Indeks Harga Saham Gabungan dijadikan barometer kesehatan ekonomi suatu negara dan sebagai landasan analisis statistik atas kondisi pasar terakhir (current market).

BI Rate dapat mempengaruhi kecenderungan pengambilan keputusan investasi oleh investor di dalam pasar saham Indonesia .Oleh karena itu terdapat tingkat BI Rate akan mempengaruhi nilai Indeks Harga Saham Gabungan. Hasil penelitian yang dilakukan oleh Amin (2012) dan Susanto (2013) menunjukkan bahwa BI Rate dan SBI berpengaruh positif pada Indeks Harga Saham Gabungan. Berbeda dengan penelitian yang dilakukan oleh Raharjo (2010), Tesa (2012); Astuti (2013), Jhony (2013), Krisna (2013), dan Muchajjir (2013), dengan hasil yang menunjukkan bahwa BI Rate dan SBI justru berpengaruh negatif pada Indeks Harga Saham Gabungan. Witjaksono (2010) menjelaskan bahwa di Indonesia kebijakan tingkat BI Rate dikendalikan secara langsung oleh Bank Indonesia melalui BI Rate. BI Rate merupakan respon bank sentral terhadap tekanan Inflasi ke depan agar tetap berada pada sasaran yang telah ditetapkan. Perubahan BI Rate sendiri dapat memicu pergerakan di 
pasar saham Indonesia. Penurunan BI Rate secara otomatis akan memicu penurunan tingkat BI Rate kredit maupun deposito.

Faktor lain yang dapat mempengaruhi harga Indeks Harga Saham Gabungan adalah Inflasi. Inflasi secara sederhana dapat diartikan sebagai peningkatan harga-harga barang secara keseluruhan sehingga mengakibatkan menurunnya daya beli masyarakat. Dengan adanya kenaikan Inflasi maka secara konstan daya beli masyarakat sekarang akan lebih tinggi dibandingkan daya beli masyarakat dimasa mendatang. Inflasi menjadi salah satu penyebab utama yang mendorong investor untuk melakukan investasi, yakni untuk melindungi nilai internal harta mereka dari tingkat Inflasi sehingga mereka dapat mempertahankan daya beli barang yang mereka miliki sekarang. Dari hasil penelitian yang dilakukan oleh Sunardi \& Ula (2017) menunjukkan bahwa Inflasi berpengaruh negatif dan signifikan terhadap Indeks Harga Saham Gabungan yang tercatat di Bursa Efek Indonesia (BEI) selama periode 2005 - 2015. Hasil yang berbeda ditunjukkan dari penelitian yang dilakukan oleh Maurina, et.al. (2015) dimana tingkat Inflasi berpengaruh positif dan tidak signifikan terhadap Indeks Harga Saham Gabungan. Hasil yang berbeda ditunjukkan pula dari penelitian yang dilakukan oleh Taufiq \& Kefi (2015) dimana Inflasi berpengaruh signifikan dan positif terhadap Indeks Harga Saham Gabungan. Agustina (2016) berpendapat bahwa akibat terjadinya Inflasi adalah meningkatkan harga pokok produksi dan beban administrasi yang harus ditanggung perusahaan, sehingga meskipun tingkat penjualan perusahaan meningkat, namun tidak dapat memberikan sumbangan laba yang lebih besar pula, sehingga deviden yang akan dibagikan ke investor tentunya akan berpengaruh. Pada kondisi Inflasi yang tinggi, investor lebih cenderung untuk menunggu dan memilih untuk melihat kebijakan yang diambil oleh pemerintah dalam mengatasi masalah Inflasi, baru kemudian mengambil langkah selanjutnya.

Dapat disimpulkan bahwa ketika Inflasi dan BI Rate mengalami peningkatan maka akan menimbulkan sinyal negatif bagi para investor di pasar modal karena ketika Inflasi dan BI Rate mengalami peningkatan maka akan menurunkan minat investor untuk berinvestasi .Berdasarkan latar belakang maka dapat diambil tujuan penelitian ini ingin mengetahui seberapa besar pengaruh Inflasi, BI Rate, American Dollar, dan Politik terhadap Indeks Harga Saham Gabungan di Indonesia.

\section{Tinjauan Pustaka \\ Pengertian Indeks Harga Saham Gabungan (IHSG)}

Indeks Harga Saham Gabungan merupakan suatu indikator untuk memantau pergerakan harga seluruh saham yang terdaftar di Bursa Efek Indonesia. Indeks Harga Saham Gabungan mulai diperkenalkan pertama kali pada tanggal 1 April 1983. Menurut Ang (1997) Indeks Harga Saham Gabungan merupakan suatu nilai yang digunakan untuk mengukur kinerja saham yang tercatat dalam bursa efek. Menurut Wijaya dan Agustin (2015) salah satu indikator utama yang mencerminkan kinerja pasar modal di Indonesia saat sedang mengalami peningkatan (bullish) atau sedang mengalami penurunan (bearish) adalah Indeks Harga Saham Gabungan.

Perhitungan indeks merepresentasikan pergerakan harga saham di pasar bursa yang terjadi melalui sistem perdagangan lelang. Nilai dasar akan disesuaikan secara cepat bila terjadi perubahan modal emiten atau terdapat faktor lain yang tidak terkait dengan harga saham. Harga saham yang digunakan dalam menghitung Indeks Harga Saham Gabungan adalah harga saham di pasar regular yang didasarkan pada harga yang terjadi pada sistem lelang. Perhitungan Indeks Harga Saham Gabungan dilakukan setiap hari, yaitu setelah penutupan perdagangan setiap harinya. Dalam waktu dekat, diharapkan perhitungan Indeks Harga Saham Gabungan dapat dilakukan beberapa kali atau bahkan dalam beberapa menit, hal ini dapat dilakukan setelah sistem perdagangan otomasi diimplementasikan dengan baik 
(Paulus Situmorang, 2008).

\section{Pengaruh Inflasi Terhadap Indeks Harga Saham Gabungan (IHSG)}

Inflasi adalah kecenderungan dari naiknya harga-harga secara umum dan terus menerus selama periode tertentu. Samuelson (1995) menyatakan bahwa tingkat Inflasi adalah meningkatnya arah harga secara umum yang berlaku dalam suatu perekonomian.

Yusup (2012), mengemukakan ada dua pendapat mengenai hubungan antara tingkat Inflasi dengan harga saham. Pendapat pertama menyatakan bahwa ada korelasi positif antara Inflasi dengan harga saham (demand pull inflation) yaitu Inflasi yang terjadi karena adanya kelebihan permintaan atas jumlah barang yang tersedia. Pada keadaan ini perusahaan dapat membebankan peningkatan biaya kepada konsumen dengan proporsi yang lebih besar sehingga keuntungan perusahaan meningkat. Dengan demikian, akan meningkatkan kemampuan perusahaan untuk membayar deviden dan akan memberikan penilaian positif pada harga saham. Pendapat yang kedua menyatakan bahwa ada korelasi negatif antara Inflasi dengan harga saham. Pendapat ini didasarkan pada asumsi bahwa Inflasi yang terjadi adalah (cost push inflation), yaitu Inflasi yang terjadi karena kenaikan biaya produksi, dengan adanya kenaikan harga bahan baku dan tenaga kerja, sementara perekonomian dalam keadaan Inflasi maka produsen tidak mempunyai keberanian untuk menaikkan harga produknya.

\section{Pengaruh BI Rate Terhadap Indeks Harga Saham Gabungan (IHSG)}

BI Rate merupakan indikator yang mencerminkan kebijakan moneter dalam merespon prospek pencapaian sasaran Inflasi ke depan, melalui pengelolaan likuiditas di pasar uang (SBI dan PUAB). Sasaran operasional kebijakan moneter dicerminkan pada perkembangan BI Rate Pasar Uang Antar Bank Overnight (PUAB O/N). Pergerakan di BI Rate PUAB ini diharapkan akan diikuti oleh perkembangan di BI Rate deposito, dan pada gilirannya BI Rate kredit perbankan (Sunardi \& Ula, 2017).

Menurut teori klasik, tabungan merupakan fungsi dari tingkat bunga. Keinginan masyarakat untuk menabung sangat tergantung pada tingkat bunga. Tingkat bunga yang tinggi, maka berhubungan positif dengan keinginan masyarakat untuk menabung akan besar, hal tersebut dikarenakan tingkat BI Rate sebagai balas jasa atau hadiah yang diterima seseorang dengan menabung. Serupa dengan tabungan, investasi merupakan fungsi tingkat bunga. Tingkat bunga yang tinggi akan menyebabkan hubungan yang negatif dengan keinginan masyarakat untuk melakukan investasi kecil, dikarenakan keuntungan dari investasi tersebut akan lebih kecil dari tingkat bunga (biaya pinjaman).

\section{Pengaruh American Dollar Terhadap Indeks Harga Saham Gabungan (IHSG)}

American Dollar merupakan BI Rate terkini dari negara-negara utama di seluruh dunia, yang ditetapkan oleh masing-masing bank sentral. Pada penelitian ini kami menerapkan sistem BI Rate internasional amerika atau disebut American Dollar adalah kurs referensi harian dari BI Rate yang ditawarkan dalam pemberian pinjaman tanpa jaminan oleh suatu bank kepada bank lainnya di pasar uang Amerika.

Pada penelitian terdahulu menjelaskan bahwa adanya hubugan yang positif antara pasar modal Indonesia dengan pasar modal Amerika serikat. Hal ini menimbulkan konsekuensi bahwa pergerakan pasar modal Indonesia akan dipengaruhi oleh pergerakan pasar modal dunia baik secara langsung maupun secara tidak langsung.

\section{Pengaruh Politik Terhadap Indeks Harga Saham Gabungan (IHSG)}

Tahun politik merupakan tahun yang dinanti bagi kita semua. Tidak hanya bagi partai politik yang berharap pasangan calon yang diusung menang, bagi masyarakat biasa, tahun 
politik juga memberikan arti tersendiri. Masyarakat berharap bisa melahirkan pemimpin yang jujur dan bertanggung jawab.

Usai tahun pemilu 2014, misalnya, aliran masuk modal asing mencapai US\$ 26 miliar dalam setahun. Aliran tersebut meningkat di tengah ketidakpastian global. Sementara pada masing-masing mencapai US\$ 20 miliar dan US\$ 21 miliar. Meski pada tahun politik faktor politik memang tidak terlalu dikhawatirkan oleh investor seperti halnya kondisi ekonomi global. Terkait kondisi politik saat ini responden investor institusi menyakini bahwa saat ini politik dalam negeri dalam kondisi yang stabil terlepas dari dinamika yang berkembang di masyarakat.

\section{Penelitian Terdahulu}

Penelitian ini mengacu pada hasil peneitian terdahulu yang terkait dengan topik penelitian ini. Kajian penelitian terdahulu diperlukan sebagai bahan referensi bagi peneliti dalam menentukan metode analisis data yang digunakan dalam pengolahan data serta sebagai pembanding dengan penelitian yang dilakukan oleh peneliti sebelumnya.

Tabel 1 Penelitian Terdahulu

\begin{tabular}{|c|c|c|c|c|}
\hline No & Nama peneliti & Tahun & Judul & Hasil penelitian \\
\hline 1. & $\begin{array}{c}\text { Gurnito Ari } \\
\text { Danardono dan } \\
\text { Musaroh, M. Si }\end{array}$ & 2013 & $\begin{array}{l}\text { Analisis } \\
\text { determinan } \\
\text { perubahan } \\
\text { indeks harga } \\
\text { sahamn } \\
\text { gabungan di } \\
\text { bursa efek } \\
\text { indonesia }\end{array}$ & $\begin{array}{l}\text { Berdasarkan analisis data secara parsial } \\
\text { perubahan indeks dow jones dan hang } \\
\text { seng yakni signifikan dan positif } \\
\text { terhadap perubahan Indeks Harga Saham } \\
\text { Gabungan, sedangkan perubahan kurs } \\
\text { berpengaruh negatif dan signifikan } \\
\text { terhadap perubahan Indeks Harga Saham } \\
\text { Gabungan. }\end{array}$ \\
\hline 2. & $\begin{array}{l}\text { Zakaria, Abdullah } \\
\text { Aminu dan Victor } \\
\text { Pattiasina }\end{array}$ & 2018 & $\begin{array}{c}\text { Determinan } \\
\text { Indeks Harga } \\
\text { Saham } \\
\text { Gabungan di } \\
\text { bursa efek } \\
\text { indonesia } \\
\end{array}$ & $\begin{array}{l}\text { Hasil penelitian ini menunjukkan bahwa } \\
\text { Inflasi, BI Rate (SBI), nilai tukar, dan } \\
\text { cadangan devisa berpengaruh terhadap } \\
\text { Indeks Harga Saham Gabungan. }\end{array}$ \\
\hline 3. & Natalia Yustitia & 2015 & $\begin{array}{l}\text { Faktor-faktor } \\
\text { yang } \\
\text { mempengaruhi } \\
\text { pergerakan } \\
\text { indek saham } \\
\text { gabungan di } \\
\text { bursa efek } \\
\text { Indonesia }\end{array}$ & 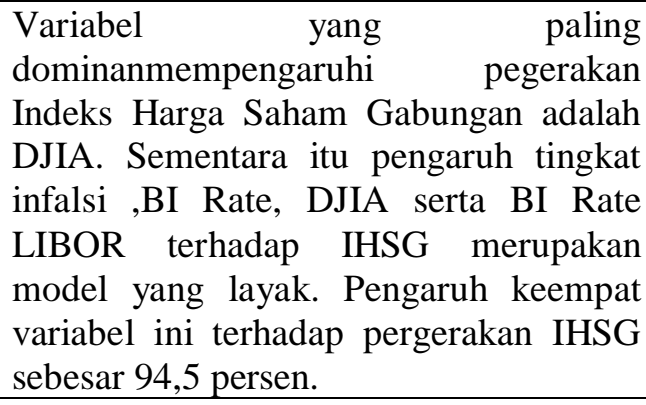 \\
\hline 4. & $\begin{array}{l}\text { Ni LuhGede Ari } \\
\text { Luwihadi dan } \\
\text { Sudarsana Arka }\end{array}$ & 2015 & $\begin{array}{c}\text { Determinan } \\
\text { jumlah uang } \\
\text { beredar dan } \\
\text { tingkat Inflasi di } \\
\text { indonesia } \\
\text { periode 1984- } \\
2014\end{array}$ & $\begin{array}{l}\text { Hasil analisis secara langsung } \\
\text { menunjukkan BI Rate berpengaruh } \\
\text { negatif dan signifikan terhadap jumlah } \\
\text { uang beredar, kurs dollar Amerika } \\
\text { berpengaruh positif dan signifikan } \\
\text { terhadap jumlah uang beredar, BI Rate } \\
\text { berpengaruh positif dan signifikan } \\
\text { terhadap tingkat Inflasi, kurs dollar } \\
\text { Amerika berpengaruh positif dan } \\
\text { signifikan terhadap Inflasi dan jumlah }\end{array}$ \\
\hline
\end{tabular}




\begin{tabular}{|c|c|c|c|c|}
\hline No & Nama peneliti & Tahun & Judul & Hasil penelitian \\
\hline & & & & $\begin{array}{l}\text { uang beredar tidak berpengaruh } \\
\text { signifikan terhadap tingkat Inflasi. } \\
\text { Secara tidak langsung menunjukkan BI } \\
\text { Rate dan kurs dollar Amerika tidak } \\
\text { berpengaruh terhadap tingkat Inflasi } \\
\text { melalui jumlah uang beredar. }\end{array}$ \\
\hline 5. & $\begin{array}{c}\text { Catona Machtra, } \\
\text { Fakhruddin, dan } \\
\text { Keywords }\end{array}$ & 2016 & $\begin{array}{l}\text { analisis efek } \\
\text { kebijakan } \\
\text { moneter } \\
\text { terhadap output } \\
\text { di indonesia }\end{array}$ & $\begin{array}{l}\text { Hasil penelitian menunjukkan bahwa } \\
\text { produk domestik bruto, Inflasi dan nilai } \\
\text { tukar memiliki hubungan saling } \\
\text { memengaruhi satu sama lainnya, serta } \\
\text { bekerja secara efektif untuk mencapai } \\
\text { tingkat pertumbuhan ekonomi yang } \\
\text { tinggi secara berkelanjutan dengan tetap } \\
\text { mempertahankan kestabilan } \\
\text { nilai rupiah. }\end{array}$ \\
\hline 6. & $\begin{array}{c}\text { ABDUL } \\
\text { ROCHMAN }\end{array}$ & 2018 & $\begin{array}{l}\text { determinan } \\
\text { variabel yang } \\
\text { mempengaruhi } \\
\text { IHSG (IHSG) di } \\
\text { bursa efek } \\
\text { indonesia (bei) }\end{array}$ & $\begin{array}{l}\text { Tingkat BI Rate, Inflasi, Gross Domestic } \\
\text { Product, Crude Oil Price, Indeks KLSE, } \\
\text { dan } \\
\text { Strait Times Index dimana berpengaruh } \\
\text { sebesar } 86,50 \% \text { terhadap Indeks Harga } \\
\text { Saham Gabungan (IHSG). }\end{array}$ \\
\hline
\end{tabular}

Sumber : diolah peneliti, 2019

\section{Kerangka Konseptual}

Grafik 2 Kerangka Konseptual



Kerangka konseptual Penelitian ini bertujuan untuk melihat apakah ada hubungan antara American Dollar (Suku Bunga internasional), BI Rate (Suku Bunga Indonesia), Inflasi, serta peranan di tahun politik, terhadap Indeks Harga Saham Gabungan secara simultan dan parsial. Serta untuk mengetahui seberapa besar faktor-faktor variabel moneter yang 
mempengaruhi pergerakan Indeks Harga Saham Gabungan.

\section{Metode Penelitian}

\section{Jenis Data dan Sumber Data}

Jenis data yang digunakan dalam penelitian ini adalah data runtun waktu (time series) periode tahun 2005 sampai tahun 2018. Sumber data dari penelitian ini diperolehh dari data tahunan yang merupakan data sekunder yaitu berupa publikasi dari lembaga relevan dengan penelitian ini. Data harga saham di masing-masing negara digunakan Indeks Harga Saham Gabungan atau Jakarta Composite Index (JCI). Sedangkan variabel tingkat bunga atau BI Rate yang digunakan adalah tingkat BI Rate di Indonesia berdasarkan data publikasi lembaga terkait. Variabel Inflasi yang digunakan adalah tingkat Inflasi tahunan yang merupakan perubahan kenaikan harga-harga umum secara terus menerus, yang dihitung dari perubahan Harga Konsumen Gabungan. Sedangkan variabel Suku bunga International yang digunakan pada penelitian ini yaitu menggunakan data Amarican dollar yang diambil secara periodik tahunan. Penelitian ini juga melibatkan data politik yaitu mengenai pemilu yang ada di Indonesia untuk mengetahui hubungan yang terjadi pada Indeks Harga Saham Gabungan terhadap suasana saat pemilu berlangsung.

\section{Objek Penelitian}

Penelitian ini dilakukan di Indonesia dengan objek penelitian dari Indeks Harga Saham Gabungan yang diteliti dengan data time series. Selain itu juga penelitian ini juga menggunakan data Inflasi dan BI Rate untuk mengukur pengaruh pergerakan IHSG serta data LIBOR untuk mengetahui pengaruhny aterhadap Indeks Harga Saham Gabungan.

\section{Hipotesis Penelitian}

Hipotesis penelitian ini menjelaskan dugaan sementara terhadap determinan variabel moneter yang mempengaruhi Indeks Harga Saham Gabungan di Indonesia.

$\mathrm{HO}=$ Variabel moneter BI Rate dan Inflasi tidak memiliki pengaruh terhadap variabel IHSG di Indonesia

H1 = Variabel moneter BI Rate dan Inflasi memiliki pengaruh terhadap variabel IHSG di Indonesia

\section{HASIL DAN PEMBAHASAN Hasil Uji Statistik}

\section{Uji Regresi Linier Berganda}

Regresi adalah bentuk hubungan fungsional antara variabel-variabel. Analisis regresi adalah suatu analisis yang digunakan untuk mengukur pengaruh variabel bebas terhadap variabel terikat. Jika pengukuran pengaruh ini melibatkan dua variabel bebas $(\mathrm{X})$ dan variabel terikat (Y) maka dinamakan analisis regresi linier berganda. 
Tabel 2. Hasil Uji Regresi Linier Berganda

\begin{tabular}{c|c|c}
\hline Variabel & Koefisien & $T_{\text {hitung }}$ \\
\hline Konstanta & 9.601972 & 12.16 \\
Inflasi & -.0840936 & -2.96 \\
BI Rate & -.0068338 & -0.84 \\
American Dollar & -.2637465 & -1.72 \\
Politik & -.0521334 & -0.16 \\
Adj R & 0.5679 & \\
& & \\
& & \\
\hline
\end{tabular}

Sumber : Data diolah, 2019

Berdasarkan hasil analisis regresi pada tabel satu, yaitu :

$Y_{i t}=\beta_{0}+\beta_{1} \operatorname{Infl}_{i t}+\beta_{2} B r_{i t}+\beta_{3} A d_{i t}+\beta_{4} P l t k_{i t}+\mathfrak{u}_{i t}$, maka persamaan regresi diperoleh : IHSG $=9.601-0.084$ Inf $-0.683 \mathrm{Br}-0.263 \mathrm{Ad}-0.052$ Pltk $+\mathfrak{u}_{i t}$,

1. Nilai konstanta sebesar 9.601972, menyatakan bahwa jika variabel independen dianggap konstan, maka Indeks Harga Saham Gabungan akan meningkat sebesar 9. 6 persen.

2. Koefesien regresi Inflasi sebesar -.0840936yang artinya jika Inflasi meningkat sebesar 1 persen , maka Indeks Harga Saham Gabungan akan menurun sebesar 8 persen.

3. Koefesien regresi BI Rate sebesar -.0068338 yang artinya jika BI Rate meningkat sebesar persen, maka Indeks Harga Saham Gabungan akan menurun sebesar 0,6 persen.

4. Koefesien regresi American dollar sebesar -.2637465 persen yang artinya jika American dollar meningkat sebesar 1 persen maka Indeks Harga Saham Gabungan akan menurun sebesar 26 persen.

5. Koefesien regresi tahun politik sebesar -.0521334 yang artinya jika tahun politik meningkat sebesar 1 persen maka Indeks Harga Saham Gabungan akan menurun sebesar 5 persen.

\section{Hasil Uji F (Uji Simultan)}

Tabel 3 Hasil Uji $\mathrm{f}$

ANOVA $^{\mathrm{a}}$

\begin{tabular}{c|c|c|r|r|r|c}
\hline \multirow{3}{*}{ Model } & & $\begin{array}{l}\text { Sum of } \\
\text { Squares }\end{array}$ & Df & Mean Square & \multicolumn{1}{c|}{ F } & Sig. \\
\hline \multirow{2}{*}{1} & Model & 2.77758436 & 4 & .69439609 & 5.27 & 0.0182 \\
\cline { 2 - 7 } & Residual & 1.18541269 & 9 & .131712521 & & \\
\cline { 2 - 7 } & Total & 3.96299705 & 13 & .304845927 & & \\
\hline
\end{tabular}

a. Dependent Variable: IHSG

b. Predictors: (Constant), american dollar, BI Rate, Inflasi, tahun politik

Sumber : Data diolah, 2019

Dari hasil analisis data uji $\mathrm{f}$ atau uji simultan atau uji keseluruhan variabel diperoleh 
Nilai f 5.27 dengan tingkat signifikansi 0.000 dimana nilai signifikansi $0.0182<0,05$ yang diartikan bahwa secara simultan hubungan antara variabel Inflasi, BI Rate, American Dollar, dan Politik memiliki hubungan yang signifikan terhadap Indeks Harga Saham Gabungan di indonesia.

\section{Uji Parsial ( Uji t)}

Uji parsial yaitu untuk menguji bagaimana pengaruh masing-masing variabel bebasnya secara sendiri sendiri terhadap variabel terikatnya. Untuk mengetahui bagaiaman hasil uji t, telah terdiskripsi pada tabel berikut :

Tabel 4. Uji t

\begin{tabular}{r|rrrrrr}
\hline IHSG & Coef. & Std. Err. & $t$ & $\mathrm{P}>|t|$ & [95\% Conf. Interval] \\
\hline $\operatorname{var2}$ & -.2637465 & .1533617 & -1.72 & 0.120 & -.6106749 & .0831818 \\
$\operatorname{var3}$ & -.0068338 & .0081596 & -0.84 & 0.424 & -.0252921 & .0116245 \\
$\operatorname{var} 4$ & -.0840936 & .028381 & -2.96 & 0.016 & -.1482959 & -.0198914 \\
$\operatorname{var5}$ & -.0521334 & .324896 & -0.16 & 0.876 & -.7870993 & .6828325 \\
_cons & 9.601972 & .7898803 & 12.16 & 0.000 & 7.815139 & 11.38881 \\
\hline
\end{tabular}

Sumber : Data diolah,2019

Tabel uji t menunjukkan bahwa variabel Inflasi, BI Rate, American Dollar dan Politik memilki pengaruh yang negatif terhadap Indeks Harga Saham Gabungan di Indonesia. Namun, variabel yang memiliki pengaruh signifikan terhadap Indeks Harga Saham Gabungan yaitu variabel Inflasi. Artinya, hal ini menandakan bahwa ketika variabel Inflasi, BI Rate, American Dollar, dan Politik mengalami penurunan maka Indeks Harga Saham Gabungan mengalami peningkatan dan begitupula sebaliknya.

\section{Kesimpulan}

Berdasarkan hasil penelitian dan analisis data, artikel yang berjudul "Determinan variabel moneter terhadap Indeks Harga Saham Gabungan di Indonesia" dapat ditarik kesimpulan bahwa secara parsial ketika variabel Inflasi, BI Rate, dan American dollar dan Politik mengalami penurunan maka Indeks Harga Saham Gabungan mengalami peningkatan dan begitupula sebaliknya. Namun, variabel inflasi mempunyai pengaruh yang negatif dan signifikan terhadap variabel Indeks Harga Saham Gabungan. Hal ini menandakan bahwa pengaruh negatif yang ditimbulkan variabel Inflasi sangat penting untuk dikaji lebih dalam. Secara simultan Inflasi, BI Rate, American dollar, dan tahun Politik memilki pengaruh yang signifikan terhadap Indeks Harga Saham Gabungan.

\section{Saran}

Model yang dikembangkan dalam penelitian ini masih terbatas karena hanya melihat pengaruh dari beberapa variabel seperti Inflasi, BI Rate, American Dollar, dan Politik terhadap Indeks Harga Saham Gabungan di indonesia. Oleh karenanya diperlukan studi lanjutan yang lebih mendalam dengan data dan metode yang lebih lengkap sehingga dapat melengkapi hasil penelitian yang telah ada dan hasilnya dapat dipergunakan sebagai bahan pertimbangan berbagai pihak.

penelitian selanjutnya di harapkan menggunakan data yang relevan dan dalam rentan waktu jangka panjang. Penelitian ini hanya menggunakan variabel ekonomi makro sebagai ukuran kinerja Indeks Harga Saham Gabungan, padahal masih banyak faktor lain yang bisa 
mempengaruhi objek penelitian. Penelitian selanjutnya perlu dikaji/ diteliti yaitu GDP, Jumlah Uang yang beredar dan dapat juga menambah variabel ekonomi mikro.

\section{UCAPAN TERIMAKSIH}

Puji syukur penulis panjatkan kepada Allah Yang Maha Kuasa, sehingga dapat menyelesaikan penelitian ini dengan diberikan kemudahan dan tepat waktu. Oleh karena itu, dalam kesempatan penulis ingin berterima kasih kepada pihak yang telah membantu dalam penyusunan peneliatian ini hingga dengna selesai:

1. Bapak Muhamad Faisal Akbar, S.E., M.Si selaku pembimbing serta penasehat dalam penyususnan penelitian.

2. Devi Putri selaku pemberi ide dalam kajian pustaka dan sumber data. Serta rekan rekan yang telah berkontribusi dan menyalurkan ide dan gagasan dalam penyusunan penelitian ini, Andre Riswanto, Jepriz Kila, Choirunnisa, Agung Pratama, dan Gebila.

\section{REFERENSI}

Gurnito Ari Danardono dan Musaroh, M.Si (2013), Analisis determinan perubahan Indeks Harga Saham Gabungan.

Zakaria, Abdullah Aminu dan Victor Pattiasina (2018), Determinan Indeks Harga Saham Gabungan di Bursa Efek Indonesia.

Natalia Yustita (2015) Faktor - faktor yang mempengaruhi pergerakan Indeks Harga Saham Gabungan di Bursa Efek Indonesia.

Ni Luh Gede Ari Luwihadi dan Sudarsana Arka (2015), Determinan Jumlah Uang Beredar dan Tingkat Inflasi di Indonesia Periode 1984-2014. EP-Jurnal EP Unud Fakultas Ekonomi dan Bisnis Universitas Udayana, Bali, Indonesia.

Catona Machatra, Fakhruddin, dan Keywords (2016), Analisis Efek Kebijakan Moneter terhadap Output di Indonesia. Fakultas Ekonomi dan Bisnis Universitas Syiah Kuala, Indonesia.

Abdul Rochman (2018), DeterminanVariabel yang Mempengaruhi Indeks Harga Saham Gabungan di Bursa Efek Indonesia (BEI).

Dwi Wulandari (2014), Pengaruh Beberapa Variabel Moneter Terhadap Harga Saham di Lima Negara Asean. Jurnal Ekonomi Kuantitatif TerapanVol.7 No.2 Agustus2014.

Depi Megawati (2018), Analisis Determinan Jumlah Uang Beredar Di Indonesia Tahun 19872016. Skripsi Fakultas Ekonomi dan Bisnis Muhammadiyah Surakarta.

Marina dan Amiruddin K (2016), Analisis Pengaruh Tingkat Inflasi Dan Jumlah Uang Beredar Terhadap Nilai Tukar Rupiah Di Indonesia. VOL. 3 NO. 1, ECCES, Economics, Social, and Development Studies.

Iwan Setiawan (2019), Analisis Dampak Kebijakan Moneter terhadap Perkembangan Inflasi dan Pertumbuhan Ekonomi di Indonesia. Jurnal Ekonomi, Keuangan, Perbankan dan Akuntansi Vol. 1, No. 1, Mei 2009, 15 - 31. 